\title{
PREPARATION OF COPPER OXIDE NANOSTRUCTURE THIN FILM FOR CARBON MONOXIDE GAS SENSOR
}

\section{PEMBUATAN LAPISAN TIPIS TEMBAGA OKSIDA BERSTRUKTUR NANO UNTUK SENSOR GAS KARBON MONOKSIDA}

\author{
Brian Yuliarto $^{1,2}$, Suyatman $^{1 *}$, Ni Luh Wulan Septiani ${ }^{1,2}$, Nugraha ${ }^{1,2}$, Gentry Rafa ${ }^{1}$ \\ ${ }^{1}$ Advanced Functional Materials Laboratory, Engineering Physics Department, \\ Institut Teknologi Bandung, Bandung, Indonesia \\ ${ }^{2}$ Research Center for Nanosciences and Nanotechnology, Institut Teknologi Bandung, Bandung, \\ Indonesia \\ email: yatman@tf.itb.ac.id
}

Received 18 August 2016; Accepted 28 October 2016; Available online 29 November 2016

\begin{abstract}
This work reports the synthesis of the nanostructure of $\mathrm{CuO}$ thin film using dip coating and chemical bath deposition method. Seed layer was deposited by dip coating method using zinc nitrate as a precursor. The $\mathrm{CuO}$ nanostructure has been successfully grown using $\mathrm{CBD}$ process at $95{ }^{\circ} \mathrm{C}$ for 6 hours. The X-Ray Diffraction characterization result shows that the $\mathrm{CuO}$ has monoclinic crystallization and good crystallinity. Moreover, the Scanning Electron Microscope characterization results show that $\mathrm{CuO}$ has nanospike-like shape. The $\mathrm{CuO}$ thin film as a gas sensor shows a relatively high response on $\mathrm{CO}$ gas at the temperature working above $200{ }^{\circ} \mathrm{C}$. The highest response is obtained at $350{ }^{\circ} \mathrm{C}$ of working temperature toward $30 \mathrm{ppm} \mathrm{CO}$ gas at $186 \%$ of sensor response.
\end{abstract}

Keywords: Copper oxide, nanostructure thin films, carbon monoxide, gas sensor.

\begin{abstract}
ABSTRAK
Artikel ini melaporkan pembuatan atau sintesis lapisan tipis $\mathrm{CuO}$ berstruktur nano menggunaan metode dip coating dan chemical bath deposition. Lapisan seed di deposisikan dengan metode dip coating menggunakan zinc nitrat sebagai precursor. $\mathrm{CuO}$ berstruktur nano telah berhasil ditumbuhkan dengan proses CBD pada temperatur $95{ }^{\circ} \mathrm{C}$ selama 6 jam. Karakterisasi dengan menggunakan $X$-Ray Diffraction menunjukan bahwa $\mathrm{CuO}$ memiliki struktur kristal monoklinik dan memiliki kristalinitas yang baik. Selain itu, karakterisasi dengan menggunakan Scanning Electron Microscope menunjukan bahwa $\mathrm{CuO}$ memiliki bentuk morfologi nanospike-like. Lapisan tipis $\mathrm{CuO}$ sebagai sensor gas menghasilkan respon yang relatif tinggi pada suhu di atas $200{ }^{\circ} \mathrm{C}$. Respon tertinggi terhadap $30 \mathrm{ppm}$ gas $\mathrm{CO}$ diperoleh $\mathrm{CuO}$ pada temperatur kerja $350{ }^{\circ} \mathrm{C}$ yaitu $186 \%$.
\end{abstract}

Kata kunci : Tembaga oksida, lapisan tipis berstruktur nano, karbon monoksida, sensor gas.

\section{INTRODUCTION}

In recent times, the fast growing of vehicles has affected greatly on air quality especially in big cities Indonesia. Based on Statistic Center Agency, the growing of the vehicles reaches $10.39 \%$ every year (Badan Pusat Statistik, 2014). The vehicles emit the harmful gasses including carbon monoxide (CO) which is very dangerous for both human and environment (Arabloo et al., 2015; Gosh.,
2014; Yuliarto.,2015). This gas is colorless and odorless so that it is very difficult to be detected by a human. CO can bind hemoglobin in red blood and prevent red blood cells to bind oxygen (Gosh, Narjinary, Sen, Bandyopadhyay, \& Roy, 2014). This gas can cause death if inhaled in high concentration (Arabloo et al., 2015; Gosh., 2014; Yuliarto.,2015). The characteristic and the dangerous of $\mathrm{CO}$ gas yield the demand of gas sensor to 
detect the existence and monitor the concentration of $\mathrm{CO}$ gas.

Gas sensor based on metal oxide becomes the favorite because it has high sensitivity and relatively low cost (Yuliarto, 2015; Septiani, 2016). In recent years, decreasing the size of metal oxide become the main focus because particles with nanoscale size significantly improve the properties of metal oxide compare with the bulk form (Javed, Usman, Tabassum, \& Zia, 2016). In the case of the gas sensor, decreasing size of metal oxide can significantly improve the sensitivity. Copper oxide $(\mathrm{CuO})$ is one of p-type semiconductor that has band gap range 1.21-1.51 eV and has potential as a gas sensor (Muiva, 2016; Ayesh, 2016; Liu, 2016). $\mathrm{CuO}$ has high catalytic activity, unique electrochemical characteristic and high oxygen adsorption (Asad \& Sheikhi, 2016). There are many methods that have been developed for the synthesis of this material such as hydrothermal and solvothermal. In this work, we used Chemical Bath Deposition (CBD) to fabricate $\mathrm{CuO}$ nanostructure thin film. CBD is one of wet route method that has several advantages including simple set up, low-cost equipment, large scale production, easy to adjustment the parameter and relatively low-temperature synthesis (Manthina, 2016; Shi, 2016; Bahramian, 2016). The resulting $\mathrm{CuO}$ nanostructure thin films deposited by CBD were then testing toward $\mathrm{CO}$ gas at various working temperature and concentrations.

\section{EXPERIMENTAL SECTION}

The materials that used in this work are $\mathrm{Zn}\left(\mathrm{CH}_{3} \mathrm{COO}\right)_{2} \cdot 6 \mathrm{H}_{2} \mathrm{O}, \quad \mathrm{Cu}\left(\mathrm{NO}_{3}\right)_{2}$. $3 \mathrm{H}_{2} \mathrm{O}$, Hexamethyl Tetraamine (HMTA), and deionized water. All the materials are pro analysis and used without any further purification. The first step in this work is seed layer deposition on the substrate by dip coating method. The solution for dip process was prepared by mix $\mathrm{Zn}\left(\mathrm{CH}_{3} \mathrm{COO}\right)_{2} \cdot 6 \mathrm{H}_{2} \mathrm{O}$, HMTA, and deionized water. A certain amount of
$\mathrm{Zn}\left(\mathrm{CH}_{3} \mathrm{COO}\right)_{2} \cdot 6 \mathrm{H}_{2} \mathrm{O}$ and $\mathrm{HMTA}$ were mixed by a magnetic stirrer in $60 \mathrm{~mL}$ deionized water at $60{ }^{\circ} \mathrm{C}$ for 1 hour. After several time of washed using water, the alumina substrate was dipped in the solution for 10 seconds and was dried in the microwave at $100{ }^{\circ} \mathrm{C}$ for 30 minutes. The next step is deposition of $\mathrm{CuO}$ nanostructure thin films by $\mathrm{CBD}$ process. Several amounts of $\mathrm{Cu}\left(\mathrm{NO}_{3}\right)_{2} \cdot 3 \mathrm{H}_{2} \mathrm{O}$ dan HMTA were mixed with a stirrer for 60 minutes at room temperature. The substrate having seed layer was then immersed in the solution for 6 hours at 95 ${ }^{\circ} \mathrm{C}$. After that, the samples were then calcined at $450{ }^{\circ} \mathrm{C}$ for 2 hours.

The crystallinity, morphology and composition of $\mathrm{CuO}$ nanostructure thin films were investigated by X-Ray Diffraction (XRD), Scanning Electron Microscope (SEM), and Energy Disperse, respectively. The $\mathrm{CO}$ gas sensor testing was conducted at $200-350{ }^{\circ} \mathrm{C}$ toward 30 ppm CO. The testing was repeated for five times each sample. The sensitivity of the sensor was tested by varied the concentration of gas at 10,50 , and 100 ppm. The sensor was also tested with NO gas to get their selectivity of the sensor. Variation concentration of $\mathrm{CO}$ and $\mathrm{NO}$ were confirmed by Bacharach gas detector PCA3 type.

\section{RESULTS AND DISCUSSION}

Figure 1 shows $\mathrm{X}$-Ray diffraction pattern of $\mathrm{CuO}$ nanostructure thin films on an alumina substrate. From the pattern, there are two phases that were come from $\mathrm{CuO}$ of nanostructure thin film and $\mathrm{Al}_{2} \mathrm{O}_{3}$ of the alumina substrate. The alumina was still detected because the film is very thin which is about hundreds of nanometers so that the X-Ray could detect the alumina structure. The strong peaks of $\mathrm{CuO}$ in $2 \theta=$ $35.662^{\circ}$ dan $38.853^{\circ}$ yielded by $(-111)$ structure, indicate that the $\mathrm{CuO}$ has good crystallinity and has a monoclinic crystal structure, which is matched with JCPDS (Joint Committee of Powder Diffraction Standard) card no 41-0254. 


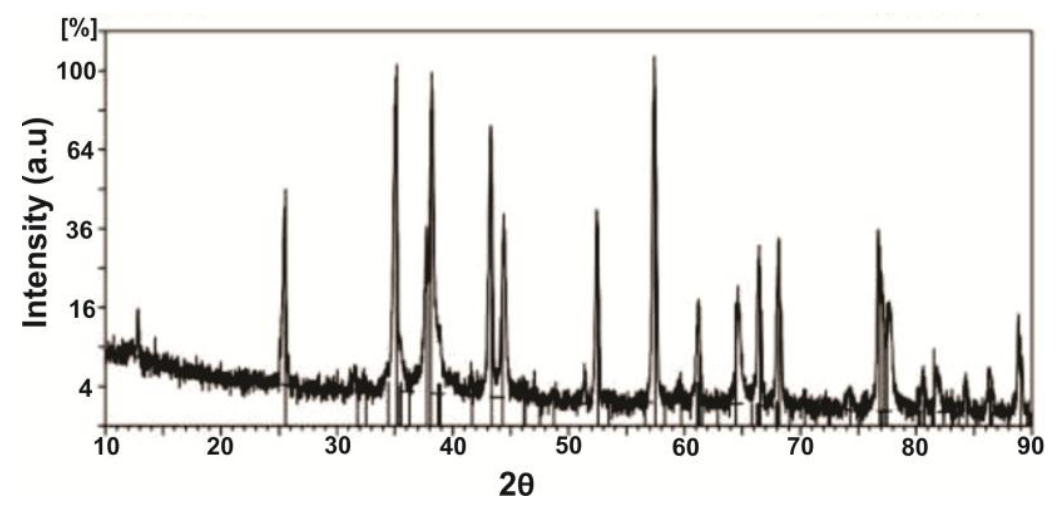

Figure 1. X-Ray Diffraction pattern of $\mathrm{CuO}$ nanostructure thin films

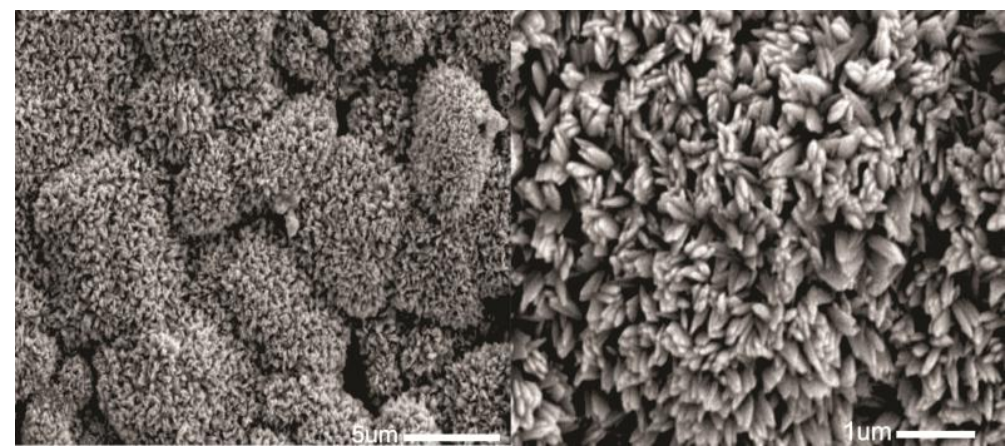

(a)

(b)

Figure 2. The SEM image of $\mathrm{CuO}$ nanostructure thin films with different magnitude with scale bar equals to (a) $5 \mu \mathrm{m}$ and (b) $1 \mu \mathrm{m}$

Figure 2 shows the morphology of $\mathrm{CuO}$ nanostructure thin film from the SEM image. It can be seen from Figure 2 that the $\mathrm{CuO}$ thin film has nano spike pattern. In the SEM image with scale bar at $5 \mu \mathrm{m}$, the $\mathrm{CuO}$ nanostructure thin films shows that incomplete agglomeration is occurred and the nano spike is not visible, but in the SEM image with scale bar $1 \mu \mathrm{m}$ the nano spike is clearly visible. The Figure 2 also shows that the $\mathrm{CuO}$ nanostructure thin film has many pores that can help the targeted gas to diffuse deeply into the sensitive layer of $\mathrm{CuO}$ nanostructure thin films and increase the response of sensor toward $\mathrm{CO}$ gas. Figure 3 shows EDS characterization result of $\mathrm{CuO}$ nanostructure thin films. It shows that there is only one phase in the thin film sample from $\mathrm{CuO}$ nanostructure thin film structure indicating that there is no impurity in the sample.

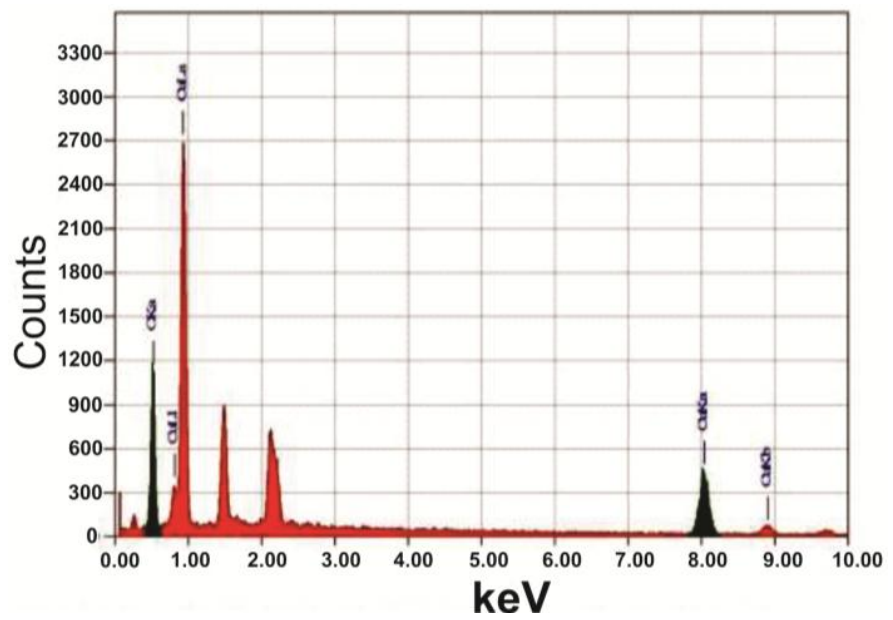

Figure 3. Energy Dispersive Spectroscopy spectrum of $\mathrm{CuO}$ nanostructure thin film 


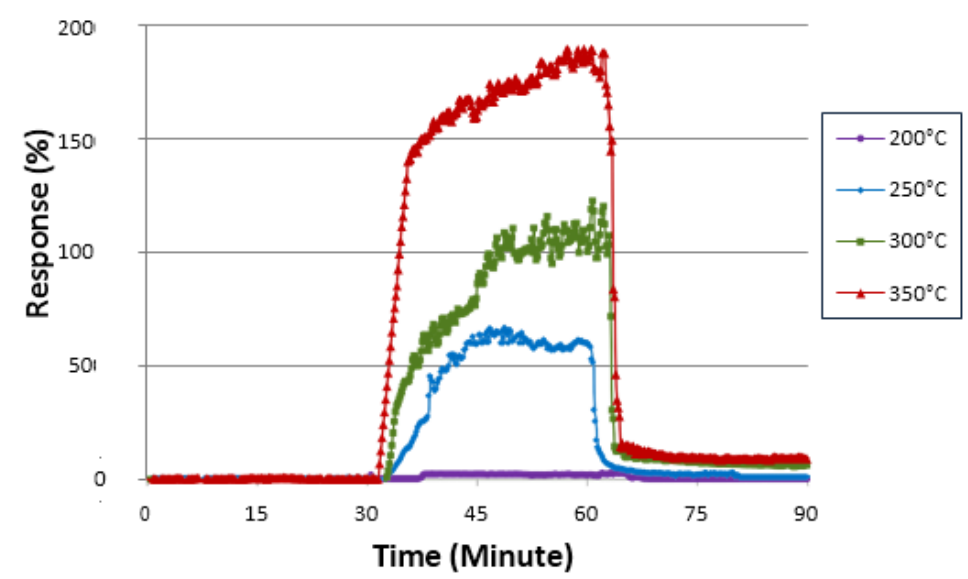

Figure 4. The typical dynamic response of $\mathrm{CuO}$ nanostructure thin film toward $30 \mathrm{ppm}$ at $200^{\circ} \mathrm{C}-350{ }^{\circ} \mathrm{C}$ of working temperature

The $\mathrm{CuO}$ nanostructure thin film is found out sensitive to the exposure of $\mathrm{CO}$ gas in the range of working temperature between $200{ }^{\circ} \mathrm{C}$ and $350{ }^{\circ} \mathrm{C}$. In this case, the $\mathrm{CuO}$ nanostructure thin film has high resistance and start to show a response at $200{ }^{\circ} \mathrm{C}$. The $\mathrm{CuO}$ thin film sensor was tested until $350{ }^{\circ} \mathrm{C}$ because the sensor with high operation temperature is not expected because of high-energy consumption as shown in Figure 4. At $200{ }^{\circ} \mathrm{C}$ the $\mathrm{CuO}$ nanostructure thin film shows very little response indicating that at the working temperature of $200{ }^{\circ} \mathrm{C}$ the reaction between targeted gas and the surface sensitive layer occurred rarely. Figure 4 shows that the sensor response toward $30 \mathrm{ppm}$ increases as the increasing of working temperature. This phenomenon occurred because at a higher temperature, the CO gas has more energy to absorb and interact with oxygen ion in the surface of $\mathrm{CuO}$ nanostructure thin film. $\mathrm{CuO}$ is p-type semiconductor where the majority carrier is a hole (Umar, 2016). CO gas is a reduction gas and the interaction between the $\mathrm{CO}$ gas, and ptype semiconductor can cause the increasing of resistance of the material. The resistance of $\mathrm{CuO}$ nanostructure thin film increases when the $\mathrm{CO}$ gas has interaction with $\mathrm{O}^{-}$ion of oxygen on the surface of $\mathrm{CuO}$ and this interaction release electrons. The electrons will recombine with the hole and decrease the charge carrier, which led to the increasing resistance of $\mathrm{CuO}$ surface. At $200{ }^{\circ} \mathrm{C}$, the resistance of $\mathrm{CuO}$ is still too high so that the changing of resistance caused by the surface reaction is very small. The surface reaction can be as follow (Yuliarto, 2015; Kocemba, 2011),

$$
\begin{aligned}
& \mathrm{CO}+\mathrm{O}^{-} \rightarrow \mathrm{CO}_{2}+e \\
& e+h \rightarrow \text { null }
\end{aligned}
$$

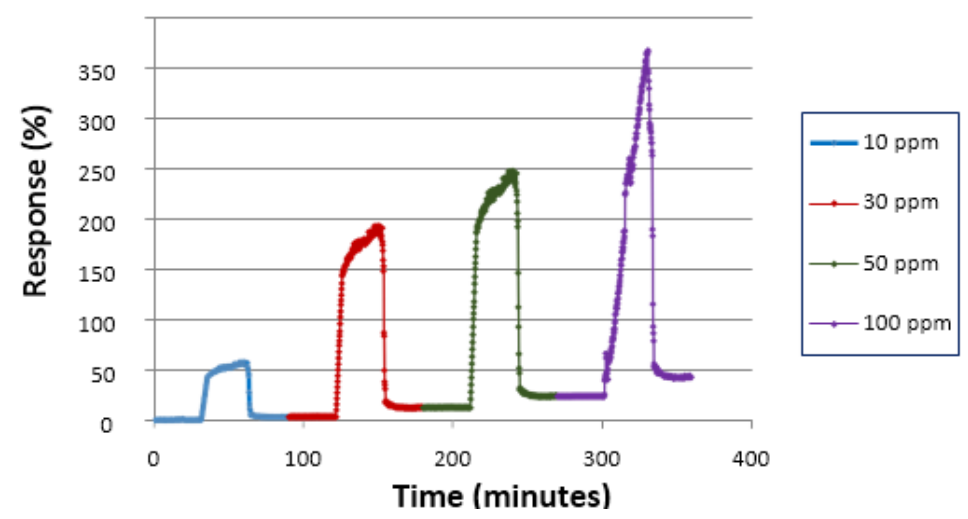

Figure 5. The sensitivity of $\mathrm{CuO}$ toward different concentration of $\mathrm{CO}$. 
Moreover, to investigate the linearity, the $\mathrm{CuO}$ nanostructure thin film sensors is exposed the $\mathrm{CO}$ gas toward various concentration on $10,30,50$, and $100 \mathrm{ppm}$ at $350{ }^{\circ} \mathrm{C}$ of working temperature. The sensor response increases as the increasing of $\mathrm{CO}$ gas concentration as shown in Figure 5 indicates that the $\mathrm{CuO}$ nanostructure thin film sensor has good linearity. The sensor also still reveals good response at the 10 ppm concentration of $\mathrm{CO}$ gas. The increasing amount of $\mathrm{CO}$ gas would increase the interaction between the $\mathrm{CO}$ gas and the surface of $\mathrm{CuO}$ nanostructure thin film sensor.

\section{CONCLUSION}

The $\mathrm{CuO}$ nanostructure thin film has been successfully fabricated on alumina substrate using dip coating and chemical bath deposition method. The resulting $\mathrm{CuO}$ nanostructure thin film has good crystallinity with nanospike pattern on the surface. The $\mathrm{CuO}$ nanostructure thin film shows a good response in the range of 200 ${ }^{\circ} \mathrm{C}$ to $350{ }^{\circ} \mathrm{C}$ toward the $30 \mathrm{ppm}$ of $\mathrm{CO}$ gas. The $\mathrm{CuO}$ nanostructure thin film sensors can detect as low as 10 ppm of $\mathrm{CO}$ gas at the working temperature of $350^{\circ} \mathrm{C}$.

\section{REFERENCES}

Arabloo, F., Javadpour, S., Memarzadeh, R., Panahi, F., Emami, M.D., Shariat, M.H. (2015).The interaction of carbon monoxide to $\mathrm{Fe}$ (III)(salen)-PEDOT:PSS composite as a gas sensor. Synthetic Metals, 209, 192-199.

Asad, M., Sheikhi, M.H. (2016). High sensitive wireless $\mathrm{H}_{2} \mathrm{~S}$ gas sensors at room temperature based on $\mathrm{CuO}$ SWCNT hybrid nanomaterials. Sensors and Actuators B: Chemical, 231, 474-483.

Ayesh, A.I., Abu-Hani, A.F.S., Mahmoud, S.T., Haik, Y. (2016). Selective $\mathrm{H}_{2} \mathrm{~S}$ sensor based on $\mathrm{CuO}$ nanoparticles embedded in organic membranes.
Sensors and Actuators B: Chemical, 231, 593-600.

Bahramian, R., Eshghi, H., Moshaii. (2016). Influence of annealing temperature on morphological, optical and UV detection properties of $\mathrm{ZnO}$ nanowires grown by chemical bath deposition. Materials \& Design, 107, 269-276.

Gosh, S., Narjinary, M., Sen, A., Bandyopadhyay, R., Roy, S. (2014). Fas detection of low concentration carbon monoxide using calciumloaded tin oxide sensors. Sensors and Actuators B : Chemical, 203, 490-496.

Javed, R., Usman, M., Tabassum, S., Zia, Muhammad. (2016). Effect of capping agent: Structural, optical and biological properties of $\mathrm{ZnO}$ nanoparticles. Applied Surface Science, 386, 319-326.

Kocemba, I., Rynkowski. (2011). The influence of catalytic on the response of $\mathrm{Pt} / \mathrm{SnO}_{2}$ gas sensors to carbon monoxide and hydrogen. Sensors and Actuators B, 155, 659666.

Liu, X., Hu, M., Wang, Y., Liu, J., Qin, Y. (2016). High sensitivity $\mathrm{NO}_{2}$ sensor based on $(\mathrm{CuO} / \mathrm{p}$-porous silicon heterojunction at room temperature. Journal of Alloys and Compounds, 685, 364-369.

Manthina, V., Agrios, A.G. (2016). Single-pot $\mathrm{ZnO}$ nanostructure synthesis by chemical bath deposition and their application. Nano-Structures \& Nano-Objects, 7 , 1-11.

Muiva, C.M., Maabong, K., Moditswe., C. (2016). $\mathrm{CuO}$ nanostructured thin films synthesized by chemical bath deposition on seed layers deposited by successive ionic layer adsorption and reaction and chemical spray pyrolysis technique. Thin Solid Films, 616, 48-54.

Septiani, N.L.W., Yuliarto, B. (2016). The development of gas sensor based on 
carbon nanotubes. Journal of The Electrochemical Society, 163, B97B106.

Shi, Z., Walker, A.V. (2016). Zinc oxide chemical bath deposition on functionalized organic thin films: Formation of nanorods, nanorockets and nanoflower. Thin Solid Films, 606, 106-112.

Suryamin. (2014). Statistik Transportasi Darat. Jakarta : Badan Pusat Statistik.

Umar, A., Lee, J.-H., Kumar, R., AlDossary, O., Ibrahim, A.A., Baskoutas, S. (2016). Development of highly sensitive and selective ethanol sensor based on lanceshaped $\mathrm{CuO}$ nanostructures. Materials \& Design,105, 16-24.
Yuliarto, B., Gumilar, G., Septiani, N.L.W. (2015). $\mathrm{SnO}_{2}$ nanostructure as pollutant gas sensors : Synthesis, sensing performances, and mechanism. Advances in Materials Science and Engineering, 2015, 114.

Yuliarto, B., Nulhakim, L., Ramadhani, M.F., Iqbal, M., Nugraha, Suyatman, Nuruddin, A. (2015). Improve performances of ethanol sensor fabricated on Al-doped $\mathrm{ZnO}$ nanosheet thin films. IEEE Sensors Journal, 15, 4114-4120. 